\title{
Prevalence of sinusitis and mastoiditis in headache
}

\author{
Baş ağrısında sinüzit ve mastoidit prevalansı \\ Cahit Polat', Murat Baykara², Salim Yüce ${ }^{3}$, İsmail Önder Uysal ${ }^{3}$, Mansur Doğan $^{3}$

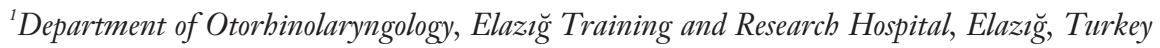 \\ ${ }^{2}$ Department of Radiology, Elazig Training and Research Hospital, Elazı̆̆, Turkey \\ ${ }^{3}$ Department of Otorbinolaryngology, Faculty of Medicine, Cumburiyet University, Sivas, Turkey
}

\begin{abstract}
Objective: To analyze the ratio of paranasal sinusitis and mastoid air cell pathologies in patients presenting with complaints of headache in the Eastern Anatolia Region of Turkey.

Methods: A total of 2750 individuals presenting with complaints of headache and underwent cranial computed tomography and brain magnetic resonance imaging between 2006 and 2010 were included in the present study. Radiological examinations were analyzed for sinusitis and mastoditis.

Results: Mastoid air cells were found to be infected in 211 (7.7\%) of 2750 cases included in the study, they were not infected in the remaining 2539 (92.3\%) cases. Paranasal sinuses were not infected in $2516(91.5 \%)$ cases and infected in $234(8.5 \%)$ cases.

Conclusion: Contrary to the popular belief, considering sinusitis as the source of headache in a person presenting with such a complaint would not be the right thing to do. Presumed prevalence of sinusitis and mastoiditis in the Eastern Anatolia Region of Turkey is consistent with the data reported in the literature.
\end{abstract}

Key words: Headache, paranasal sinusitis, mastoid air cells, radiology.

Headache is a frequently encountered symptom in neurology, and prevalence of all-cause headache in the community is over 90 percent. Various etiological factors ranging from febrile systemic diseases to serious diseases of the central nervous system can result in headache. However, majority of headaches consists of primary headache secondary to undetermined underlying factors. ${ }^{[1]}$ A significant part of the primary headaches consists of migraines, and tension-type

\begin{abstract}
Özet
Amaç: Bu çalışmanın amacı Türkiye'nin Doğu Anadolu Bölgesi'nde baş ağrısı şikayeti ile baş vuran hastalardaki, paranazal sinüs ve mastoid hücre patolojisi oranını analiz etmektir.

Yöntem: Çalışmaya 2006-2010 yılları arasında baş ağrısı şikayeti ile başvuran ve bu nedenle kraniyal bilgisayarlı tomografi ve beyin manyetik rezonans görüntülemesi yapılan 2750 birey alındı. Radyolojik tetkikler incelenerek sinüzit ve mastoidit yönüyle analiz edildi.

Bulgular: Çalışmaya aldığımız 2750 vakanın 211'inde (\% 7.7) mastoid hücreler enfekte olarak bulunurken 2539'unda (\%92.3) temiz olarak bulundu. Paranazal sinüsler 2516 vakada (\%91.5) temiz iken 234 vakada (\% 8.5) ise enfekte idi.

Sonuç: Toplumda sanılanın aksine baş ağrısı şikayeti ile gelen hastada ilk planda sinüzit düşünmek çok yanlış olacaktır. Türkiye'nin Doğu Anadolu Bölgesi için beklenen sinüzit ve mastoidit sıklığı literatürdeki diğer veriler ile uyumludur.
\end{abstract}

Anahtar sözcükler: Baş ağrısı, paranazal sinüsler, mastoid hücreler, radyoloji.

headache. In addition to deterioration of quality of life of the patients, ensuing labour loss, and health care expenditures are important issues to be evaluated when dealing with headaches.

The first step in dealing with a headache patient is to determine whether the patient is suffering from primary or secondary type of headache. If the headache is of secondary type, then as a second step subtype of the headache is deter-
Correspondence: Cahit Polat, MD. Department of Otorhinolaryngology,

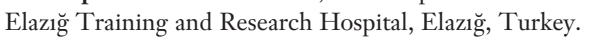

e-mail: drcahitpolat@yahoo.com

Received: July 11, 2013; Accepted: September 20, 2013; Published online: January 29, 2014
Online available at:

www.jmedupdates.org doi:10.2399/jmu.2013003008 QR code: 
mined.$^{[1,2]}$ Herein, the most important feature to be considered is that secondary headaches do not have specific discriminative characteristics, and they can imitate every type of primary headaches. Headaches in which a demonstrable structural defect, systemic disease or previous head trauma can be ruled out with the aid of medical history, physical, and neurological examination or further tests in case of need, are considered as "primary headaches." As can be understood from all information, headaches can be associated with many causative factors. It can be a life -threatening condition or an expression of undesirable life experiences. In guidelines for the international classification of headaches released by International Headache Society (IHS) in 1988, and lastly in 2004, headaches are categorized priorly in two main groups, and then their subgroups totaling to 13 separate groups. Above all, two main groups as primary and secondary headaches are in question. If a second culprit event such as tumor, infection, cerebrovascular disease, glaucoma, and acute sinusitis is responsible for the headache, then it is evaluated as "a secondary headache" ${ }^{[3]}$

Secondary headaches emerge in diseases involving nervous or other organ systems including intracranial masses, bleeding or potential predisposing factors of bleeding disorders. $^{[4]}$ Therefore, in the management of these two conditions, differential diagnosis conveys importance, and imaging modalities are also resorted. Secondary headaches have been classified as those related to head and neck traumas, cerebrocervical vascular problems, non-vascular intracranial pathologies, head and facial pains associated with adjacent organ disorders (neck, ear, teeth, and sinuses), substance abuse, infections, psychiatric disorders, and craniofacial neuralgias. ${ }^{[3]}$

In general terms, sinusitis is an inflammation of paranasal sinuses which can be induced with infectious agents, and allergic mechanisms. Though sinusitis can be classified in many ways, that related to the duration of symptoms is the most frequently used one. Terms of acute, subacute, and chronic sinusitis indicate the duration of symptoms lasting for $<4$ weeks, 4 weeks, 3 months, and more than 3 months, respectively. ${ }^{[5]}$ Variations suspected for the etiological factors of chronic sinusitis including concha bullosa, agger nasi cells, extremely pneumatized ethmoid bulla, uncinate bulla, serpentine uncinate process, Haller cells, septal deviation (SD), paradoxal middle concha, secondary middle concha, and tuberculum septi can be enumerated. For the investigation of this correlation, computed tomography is the most ideal diagnostic tool ${ }^{[6]}$ In sinusitis which is one of the etiologic factors of headaches, causes pain, and congestion especially in the anterior aspect of the face when the patient bends forward.
Headaches can originate from nose, and paranasal sinus(es), and also from middle ear, and mastoid sinuses. Otitis media, and mastoiditis present with pain localized on nose, and mastoid sinus, and typical examination findings which hardly pose diagnostic difficulties. Otoscopic examination in cases with acute-onset ear pain usually establishes diagnosis in most of the patients. Localization of pain in pediatric patients might be challenging. Chronic otitis media is a chronic infection, and inflammation, which mostly manifests itself clinically with otorrhea and hearing loss. Chronic otitis media generally develops as a result of recurrent episodes of acute otitis or chronic otitis media with effusion. Association of insufficiently aerated mastoid bone with chronic otitis media has been demonstrated. ${ }^{[7,8]}$ Despite lots of investigations related to headache have been conducted so far, our study is the first largest case series performed in the population living in the Eastern Anatolia Region of Turkey.

\section{Materials and Methods}

Our study included 2750 participants who consulted to outpatient clinics of Ear, Nose, and Throat, and Neurology Departments of Elazığ Training and Research Hospital with complaints of headache between the years 2006, and 2010, and therefore underwent routine cranial CT or MRI (magnetic resonance imaging) examinations Medical files were retrospectively surveyed to find patients with complaints of headache, and relevant radiological reports, and images were analyzed individually. Any involvement of paranasal sinuses, and mastoid cells was searched for by examining CT, and MRI images obtained, and attempts to reveal a correlation between these findings, and the presence of headache were made.

Data of our study were entered into SPSS (v. 14.0) program (SPSS Inc. Chicago, IL, USA), and chi-square test was used for the evaluation of data with an accepted bias level of 0.05 .

\section{Results}

Ages of the participants ranged from 11, and 83 years with a mean value of $46.67 \pm 19.12$ years. Study population consisted of 1371 (49.9\%) male, and 1379 (50.1\%) female participants with mean ages of $47.30 \pm 19.29$, and $46.04 \pm 18.94$ years, respectively.

In $211(7.7 \%)$ cases of our study population $(n=2750)$ mastoid cells were infected, and the remaining cases $(\mathrm{n}=2539,92.3 \%)$ had uninfected mastoid cells. Paranasal sinuses were not infected in 2516 (91.5\%) cases, while left 
$(\mathrm{n}=17,0.6 \%)$, and right $(\mathrm{n}=34,1.2 \%)$ maxillary sinusitis, left maxillary + ethmoid sinusitis $(\mathrm{n}=40,1.5 \%)$, bilateral ethmoid sinusitis $(\mathrm{n}=33,1.2 \%)$ anterior ethmoid sinusitis $(\mathrm{n}=20,1.5 \%)$, left ethmoid sinusitis $(\mathrm{n}=35,1.3 \%)$, and left sphenoid sinusitis $(\mathrm{n}=55,2 \%)$ were detected.

Mastoid cells were infected in 112 (8.16\%) male, and 99 (7.17\%) female patients. Differences between two genders were statistically insignificant when they were compared using chi-square test $(\mathrm{p}=0.329, \mathrm{p}>0.05)$. Comparative values related to mastoid cells in both genders are shown in Table 1.

Rates of paranasal sinusitis in male and female patients did not differ significantly (Table 2).

Generally speaking, involvement of the paranasal sinuses was detected in $102(7.43 \%)$ male, and 132 (9.57\%) female patients. Sinusitis was seen slightly more frequently in women without any significant difference between genders $(\mathrm{p}=0.085)$.

\section{Discussion}

In our country, it has been revealed that $38.9 \%$ of the patients who consulted to physicians are complaining of headache. Headache patients consult firstly to neurologists (36.9\%), internal medicine (27.8\%), and ENT (ear, nose, and throat) specialists. Only $16.3 \%$ of the patients consult to primary care physicians. ${ }^{[9]}$

Epidemiology of sinus headaches $(\mathrm{SH})$ is not known. It is acknowledged that painful stimuli can arise from anatomic regions totally different from those encompassed by the field of ENT discipline. A widely held common opinion states that intranasal mucosal contact points induce release of Substance -P from C- terminals of fibrils, and this type of axon reflex mechanism causes neurogenic inflammation and triggers hypersensitivity reactions with ensuing activation of trigeminal afferents, and intranasal mucosal parasympathetic fibers. ${ }^{[10]}$

Markedly apparent, and overlapping sinus symptoms lead to a misdiagnosis of sinus headache, despite the patients met the diagnostic criteria of migrainous or tension-type headaches. Still, International Headache Society (IHC) does not regard chronic rhinosinusitis as one of the etiological factors of headaches. ${ }^{[11]}$

Incidence of sinusitis which is frequently implicated by physicians, and patients as a cause of headaches, is not so high as conceived. Diagnosis of migraine has been established in many patients who had been followed up previously with an initial diagnosis of sinus headache. ${ }^{[12]}$ In a multicentered study on the epidemiology of headaches, the preva-
Table 1. Comparative evaluation of mastoid cell characteristics in our male, and female patients.

\begin{tabular}{lccc}
\hline Mastoid & Male & Female & Total \\
\hline Uninfected & 1259 & 1280 & 2539 \\
Infected & 112 & 99 & 211 \\
Total & 1371 & 1379 & 2750 \\
\hline
\end{tabular}

$p=0.329, p>0.05$

lence of migraine in the population aged 15-55 years was found to be 16.4 percent. Migraine is mostly seen among people aged 30-39 years. Prevalence of tension-type headache (TTH) was estimated to be 20-30 percent, and $3.1 \%$ for its episodic, and persistent subtypes, respectively. ${ }^{[13]}$

$\mathrm{SH}$ is an episodic pain frequently accompanied by nasal congestion involving face, and periorbital region with manifestations of rhinorrhea, sensation of pressure, and fullness in the face, watering of eyes, and nausea. Onset of SH is related to seasonal changes. ${ }^{[10]}$

Because of difficulties frequently encountered in the differential diagnosis made between migraine, tension-type, and sinus headaches, IHS added new recommendations in its 2005 guidelines. In line with these recommendations, nasal stuffiness, and discharge, sensation of fullness in the face should suggest the probability of rhinosinusitis. If symptoms of rhinosinusitis do not accompany headaches, then mucosal contact points, and intranasal structural defects should be looked for. Whether or not patient's headache is alleviated by application of decongested nasal tampons is an important diagnostic criterion. Contact points detected in septum, and conchae should be treated surgically in suitable patients. ${ }^{[14]}$

The association between insufficiently aerated mastoid bone, and atelectatic nasal diseases of the mastoid bone,

Table 2. Comparative evaluation of paranasal sinuses in our male and female patients.

\begin{tabular}{lccc}
\hline Paranasal sinuses & Male & Female & Total \\
\hline Uninfected & 1269 & 1247 & 2516 \\
Left maxillary sinusitis & 4 & 13 & 17 \\
Bilateral ethmoid & 14 & 19 & 33 \\
Anterior ethmoid & 9 & 11 & 20 \\
Left ethmoid & 17 & 18 & 35 \\
Right maxillary & 21 & 13 & 34 \\
Left maxillary+ethmoid & 15 & 25 & 40 \\
Left sphenoid & 22 & 33 & 55 \\
Total & 1371 & 1379 & 2750 \\
\hline
\end{tabular}

$p=0.085, p>0.05$ 
cholesteatoma, and chronic otitis media with effusion has been already demonstrated. ${ }^{[7,15]}$ Since mastoid air cell system develops in three dimensions within the temporal bone, some strategies have been evolved to obtain 3-D images from 2-D computed tomograms, and tomographic radiograms. User-friendly Schuller method demonstrates anteroposterior development of mastoid air cell system in two-dimensional images fairly well, however it fails to reveal mediolateral development of this system. In other words, limited number of data could be obtained using Schuller method. Therefore, it is important to evaluate the development of 3-D anatomy of mastoid air cells via computed tomographic methods. CT has an important place in the evaluation of middle ear, and temporal bone. ${ }^{[16]}$ Radiolucencies seen in T2-weighted MR images provide sufficient information related to the existence of inflammatory changes in these regions. ${ }^{[15]}$

We have conducted the largest case series involving the patient population of Eastern Anatolia Region of Turkey who presented with complaints of headache, which found the incidence rates of both sinusitis, and mastoiditis as being below 10 percent in compliance with literature findings.

\section{Conclusion}

In conclusion, contrary to the belief held in the Turkish population, presumption of sinusitis or chronic otitis and mastoiditis in a patient presenting with a headache in the foreground would be totally misleading. Anticipated frequency of sinusitis and mastoiditis in the Eastern Anatolia Region of Turkey is consistent with the data of investigations performed in other parts of the world.

Conflict of Interest: No conflicts declared.

\section{References}

1. Headache Classification Committee of the International Headache Society. Classification and diagnostic criteria for headache disorders, cranial neuralgias and facial pain. Cephalalgia 1988;8 Suppl $7: 1-96$.
2. Silberstein SD, Saper JR, Freitag FG. Migraine; diagnosis and treatment. In: Silberstein SD, Lipton RB, Dalessio DJ, editors. Wolff's headache and other pain. Oxford: Oxford University Press; 2001. p. 121-237.

3. Olesen J, Steiner TJ. The International classification of headache disorders, 2nd edn (ICDH-II). J Neurol Neurosurgery Pschiatry 2004;75:808-11.

4. Clinch CR: Evaluation of acute headaches in adults. Am Fam Physician 2001;63:685-92.

5. Jafek BW, Stark AK. KBB'nin sırları. Çev. Ed. Ç. Kaleli. İstanbul: Nobel Matbaacilik; 2002.

6. Aykut M. Sinonazal varyasyonlar ve BT. Uzmanlı Tezi. Sivas: Cumhuriyet Üniversitesi Tıp Fakültesi; 1994.

7. Bayramoğlu I, Ardiç FN, Kara CO, Ozüer MZ, Katircioğlu O, Topuz B. Importance of mastoid pneumatization on secretory otitis media. Int J Pediatr Otorhinolaryngol 1997;40:61-6.

8. Sadé J, Fuchs C. A comparison of mastoid pneumatization in adults and children with cholesteatoma. Eur Arch Otorhinolaryngol 1994;251:191-5.

9. Göksan B. Baş ă̆rılı hastanın değerlendirilmesi. In: Siva A, Hancı M, editors. Baş, boyun, bel ağrıları. İstanbul: Deomed Yayıncılık; 2002. p. 15-21.

10. Cady K, Schreiber CP. Sinus headache: a clinical conundrum. Otolaryngol Clin North Am 2004;37:267-88.

11. Headache Classification Subcommittee of the International Headache Society. The International classification of headache disorders: 2nd edition. Cephalalgia 2004;24 Suppl 1:9-160.

12. Levine HL, Setzen M, Cady RK, et al. An otolaryngology, neurology, allergy, and primary care consensus on diagnosis and treatment of sinus headache. Otolaryngol Head Neck Surg 2006:134:516-23.

13. Siva A. Baş ağrısı epidemiyolojisi. In: Siva A, Hancı M, editors. Baş, boyun, bel ağrıları. İstanbul: Deomed Yayıncılık; 2002. p. 9-14.

14. Cady RK, Dodick DW, Levine HL, et al. Sinus headache: a neurology, otolaryngology, allergy, and primary care consensus on diagnosis and treatment. Mayo Clin Proc 2005;80:908-16.

15. Yousem DM. Imaging of sinonasal inflammatory disease. Radiology 1993;188:303-14.

16. Sato K, Kawana M, Yamamoto Y, Fujioka O, Nakano Y. Evaluation of mastoid air cell system by three-dimentional reconstruction using sagittal tomography of the temporal bone. Auris Nasus Larynx 1997;24:47-51.

This is an open access article distributed under the terms of the Creative Commons Attribution-NonCommercial-NoDerivs 3.0 Unported (CC BYNC-ND3.0) Licence (http://creativecommons.org/licenses/by-nc-nd/3.0/) which permits unrestricted noncommercial use, distribution, and reproduction in any medium, provided the original work is properly cited.

Please cite this article as: Polat C, Baykara M, Yüce S, Uysal İÖ, Doğan M. Prevalence of sinusitis and mastoiditis in headache. J Med Updates 2013;3(3):146-149. 